\title{
A Study on Dimocarpus longan Peel as Corrosion Inhibitor on Steel in Artificial Brine Solutions
}

\author{
Gadang Priyotomo ${ }^{1 *}$, Siska Prifiharni ${ }^{1}$, Lutviasari Nuraini', Yanyan Dwiyanti ${ }^{2}$ and Rabin Ardiansyah ${ }^{2}$ \\ ${ }^{1}$ Research Center for Metallurgy \& Material, Indonesia \\ ${ }^{2}$ Faculty of Engineering, Indonesia
}

*Corresponding author: Gadang Priyotomo, Tangerang Selatan, Indonesia

Submission: 非 April 25, 2018; Published: 眥 May 14, 2018

\begin{abstract}
The effect of Dimocarpus longan peel extract on the corrosion behavior of API 5L steel has been studied employing potentiodynamic polarization techniques and electrochemical impedance spectroscopy in an aqueous solution of artificial brine by injected $\mathrm{CO}_{2}$ gas. The addition of that extract decreases corrosion rate of API 5L steel, increasing corrosion inhibitor efficiency of that up to an extract concentration of $400 \mathrm{ppm}$. On the basis of result, corrosion inhibitor of Dimocarpus longan peel extract is categorized as mixed inhibitor type where both the decrease of anodic and cathodic current take place with increasing the concentration of inhibitor. A shift of corrosion potential for steel is below $\pm 85 \mathrm{mV}$ vs saturated standard calomel (SCE) which refers to the presence of mixed inhibitor. Furthermore, the addition Dimocarpus longan peel extract also increase charge transfer resistance which indicates the formation of film due to molecule adsorption on the metal surface.
\end{abstract}

Keywords: Corrosion; Steel; Polarization; Impedance; Corrosion inhibitor

\section{Introduction}

Corrosion is the degradation of a metal and alloys as a result of electrochemical reactions between it and the surrounding environment. Corrosion problem has a biggest concern of industrial operation in the world. Furthermore, there are many methods to minimize the harmful corrosion process, where the use of inhibitors is one of the preferred methods for protecting metals against corrosion [1]. Especially, acid commercial inhibitors are primarily used in several units of industrial operations. In addition, several industrial processes such as acid cleaning and etching, acid solutions are used for the removal of rust and scale and the metal surfaces are often made to come in contact with the acids $[2,3]$.

Most of the commercial corrosion inhibitors are synthetic compounds which are expensive and very harmful to environments due to the toxicity of chromate, phosphates and arsenic. Due to the toxicity of several corrosion inhibitors, there are many exploration and investigation regarding to green corrosion inhibitors. Green corrosion inhibitors are biodegradable, co-friendly, cheap, renewable and ecologically anticorrosion substances [4]. Several research groups had reported the successful use of naturally occurring compounds to inhibit the corrosion of metals in acidic and alkaline environments [5-11].

Furthermore, Dimocarpus longan fruit is widely distributed in Southeast Asia, such as Indonesia, Vietnam, and Thailand. Longan pericarp tissues contain high amounts of bioactive compounds, such as polyphenolic acids, flavonoids, and polysaccharides [12]. Furthermore, the compound of polyphenols in plant extracts have been investigated to account for inhibition of acid corrosion of metals $[13,14]$. However, there is no or little investigation of Dimocarpus longan peel as a candidate of green corrosion inhibitor in artificial brine water which injected with $\mathrm{CO}_{2}$ gas. Therefore, the objective present work is to study the inhibitive performance of green corrosion inhibitor on API 5L steel in artificial brine solution with $\mathrm{CO}_{2}$ gas injection.

\section{Research Methodology}

\section{Material and solution preparation}

Table 1: Composition of materials investigated.

\begin{tabular}{|c|c|}
\hline Elements & Wt.\% \\
\hline $\mathrm{Mg}$ & 2.66 \\
\hline $\mathrm{Si}$ & 0.13 \\
\hline $\mathrm{Fe}$ & 0.27 \\
\hline $\mathrm{Cu}$ & 0.0007 \\
\hline $\mathrm{Mn}$ & 0.006 \\
\hline $\mathrm{Zn}$ & 0.12 \\
\hline $\mathrm{Cr}$ & 0.23 \\
\hline $\mathrm{Al}$ & Balanced \\
\hline
\end{tabular}


The chemical compositions (wt \%) of API 5L steel used was as follows in Table 1 . The surface of specimen $\left(1 \mathrm{~cm}^{2}\right)$ was rubbed using different grade of silica carbide grit papers (120-1000) before the electrochemical measurement. The specimen were cleaned by washing with distillate water and acetone respectively, and then kept in dried desiccator's storage before the measurement. Furthermore, the main artificial brine solutions consist of $12,874 \mathrm{mg} / \mathrm{L}$ of $\mathrm{NaCl}$, $7,374 \mathrm{mg} / \mathrm{L} \mathrm{Na}_{2} \mathrm{SO}_{4}$ and $912 \mathrm{mg} / \mathrm{L} \mathrm{NaHCO}$ mg/L. All solutions were injected by $\mathrm{CO}_{2}$ gas during the electrochemical tests.

\section{Preparation of inhibitor}

Fresh Dimocarpus longan peel was collected and washed with distillate water than shade dried for 72 hours. This dried Dimocarpus longan peel was powdered into small pieces and $40 \mathrm{~g}$ of the dried peels were refluxed with $500 \mathrm{~mL}$ of ethyl alcohol for 72 hours. After that, the extracted solution then filtered using and concentrated until the water from the extract evaporates using rotary evaporator apparatus at $35^{\circ} \mathrm{C}$. The high viscous brown liquid was obtained which is used to study the corrosion inhibition property on API 5L steel. Finally, this brown liquid was used to prepare the required concentrations of inhibitor solution.

\section{Electrochemical test}

One of electrochemical experiments was potentiodynamic polarization techniques where were conducted in a round bottom cell of $1000 \mathrm{ml}$ capacity using a potentiostat (Reference 600, Gamry Instrument), interfaced to a personal computer. The potentials were measured using a saturated calomel electrode (SCE). All the potentials referred in this work are with respect to SCE. The surface of the working electrode was covered with resin to expose a working area of $1 \mathrm{~cm}^{2}$. A platinum wire served as the counter electrode. Prior to anodic polarization test, the open circuit potential (OCP) was monitored and experiments were begun after stabilization of OCP. Those experiments were conducted at a scan rate of $0.167 \mathrm{mV} / \mathrm{s}$. The electrochemical tests were performed using various extracts concentrations ranging from 0 to $700 \mathrm{ppm}$ at ambient temperature. Furthermore, inhibition efficiency can be calculated from the electrochemical measurements by the following equation:

$$
E I \%=\frac{(C R)_{i}-(C R)_{f}}{(C R)_{i}} \times 100
$$

where $(\mathrm{CR})_{\mathrm{i}}$ and $(\mathrm{CR})_{\mathrm{f}}$ are the corrosion rate in the absence and presence of inhibitor, respectively. The corrosion potential $\left(\mathrm{E}_{\text {cor }}\right)$ and corrosion current density $\left(\mathrm{I}_{\text {cor }}\right)$ were calculated by extrapolation of anodic and cathodic tafel slopes.

The other of electrochemical test was the electrochemical AC-impedance spectroscopy (EIS) measurements, where were performed using a Gamry EIS300 electrochemical workstation. Experiments were conducted in a conventional three-electrode cell assembly as that used for potentiodynamic polarization studies. A sine wave with amplitude of $10 \mathrm{mV}$ was superimposed on the steady open circuit potential. The real part $\left(\mathrm{Z}_{\mathrm{re}}\right)$ and the imaginary part $\left(\mathrm{Z}_{\mathrm{im}}\right)$ were measured at various frequencies in the range of $1 \mathrm{KHz}$ to $30 \mathrm{MHz}$. The experiments were carried out in the absence and presence of different concentrations of the inhibitor.

\section{Results and Discussion}

\section{Potentiodynamic polarization measurements}

Polarization experiments are conducted potentiodynamically in artificial brine solution with injected $\mathrm{CO}_{2}$ gas in the absence and presence of different concentration of dimocarpus longan peel extract. Furthermore, the electrochemical parameters, namely,corrosion potential $\left(\mathrm{E}_{\text {corr }}\right)$, corrosion current density ( $\left.\mathrm{I}_{\text {corr }}\right)$, anodic Tafel slope $\left(b_{\mathrm{a}}\right)$, cathodic Tafel slope $\left(b_{c}\right)$, and percentage inhibition efficiency (IE), determined from the polarization curves are summarized in Table 2. Table 2 shows that both corrosion current density $\left(\mathrm{I}_{\text {corr }}\right)$ and corrosion rate decreased noticeably with increase in extract concentration up to $400 \mathrm{ppm}$. However, above $400 \mathrm{ppm}$ of extract concentration, they increase slightly. Inhibition efficiency of dimocarpus longan peel extract increase up to $400 \mathrm{ppm}$, and decrease above that. In addition, the corrosion potential $\left(\mathrm{E}_{\mathrm{corr}}\right)$ of API 5L steel shifts toward less negative direction which indicate that dimocarpus longan peel extract behaves as a good inhibitor as well as Canna Indica flower extract (CIFE) in $\mathrm{HCl}$ solution [15].

Table 2: Electrochemical polarization parameters for API 5L steel in artificial brine solutions with injected $\mathrm{CO}_{2}$ gas in the absence and presence of various concentrations of extract.

\begin{tabular}{|c|c|c|c|c|c|c|}
\hline $\begin{array}{c}\text { Concentration } \\
(\mathbf{p p m})\end{array}$ & $\mathbf{E}_{\text {corr }} \mathbf{( m V )}$ & $\mathbf{I}_{\text {corr }} \mathbf{( A / \mathbf { c m } )}$ & $\mathbf{b}_{(\mathbf{a} / \mathbf{c})}(\mathbf{V} / \mathbf{d e c})$ & $\begin{array}{c}\text { Corrosion Rate } \\
(\mathbf{m p y})\end{array}$ & $\begin{array}{c}\text { Inhibition } \\
\text { Efficiency(\%) }\end{array}$ & $\begin{array}{c}\text { Surface } \\
\mathbf{C o v e r a g e}(\boldsymbol{\theta})\end{array}$ \\
\hline 0 & -764.7 & $7.95 \mathrm{E}-05$ & $4.84 \mathrm{E}-01$ & 36.34 & 0 & 0 \\
\hline 50 & -754.3 & $7.06 \mathrm{E}-05$ & $5.35 \mathrm{E}-01$ & 32.36 & 10.95212 & 0.109521 \\
\hline 100 & -761.2 & $6.63 \mathrm{E}-05$ & $5.38 \mathrm{E}-01$ & 27.26 & 24.98624 & 0.249862 \\
\hline 150 & -743.1 & $5.52 \mathrm{E}-05$ & $5.25 \mathrm{E}-01$ & 25.23 & 30.57237 & 0.305724 \\
\hline 200 & -739.5 & $5.34 \mathrm{E}-05$ & $5.02 \mathrm{E}-01$ & 24.39 & 32.88387 & 0.328839 \\
\hline 250 & -775.7 & $5.04 \mathrm{E}-05$ & $3.27 \mathrm{E}-01$ & 23.02 & 36.65382 & 0.366538 \\
\hline 300 & -761.7 & $4.56 \mathrm{E}-05$ & $3.75 \mathrm{E}-01$ & 20.81 & 42.73528 & 0.427353 \\
\hline 350 & -790.4 & $4.24 \mathrm{E}-05$ & $2.72 \mathrm{E}-01$ & 19.36 & 46.72537 & 0.467254 \\
\hline 400 & -733.5 & $3.28 \mathrm{E}-05$ & $3.68 \mathrm{E}-01$ & 17.87 & 50.82554 & 0.508255 \\
\hline 450 & -802.3 & $4.90 \mathrm{E}-05$ & $3.49 \mathrm{E}-01$ & 22.39 & 38.38745 & 0.383875 \\
\hline
\end{tabular}




\begin{tabular}{|c|c|c|c|c|c|c|}
\hline 500 & -771.4 & $5.94 \mathrm{E}-05$ & $4.17 \mathrm{E}-01$ & 27.16 & 25.26142 & 0.252614 \\
\hline 600 & -784.1 & $5.67 \mathrm{E}-05$ & $4.40 \mathrm{E}-01$ & 25.91 & 28.70116 & 0.287012 \\
\hline 700 & -783 & $5.08 \mathrm{E}-05$ & $4.56 \mathrm{E}-01$ & 23.2 & 36.1585 & 0.361585 \\
\hline
\end{tabular}

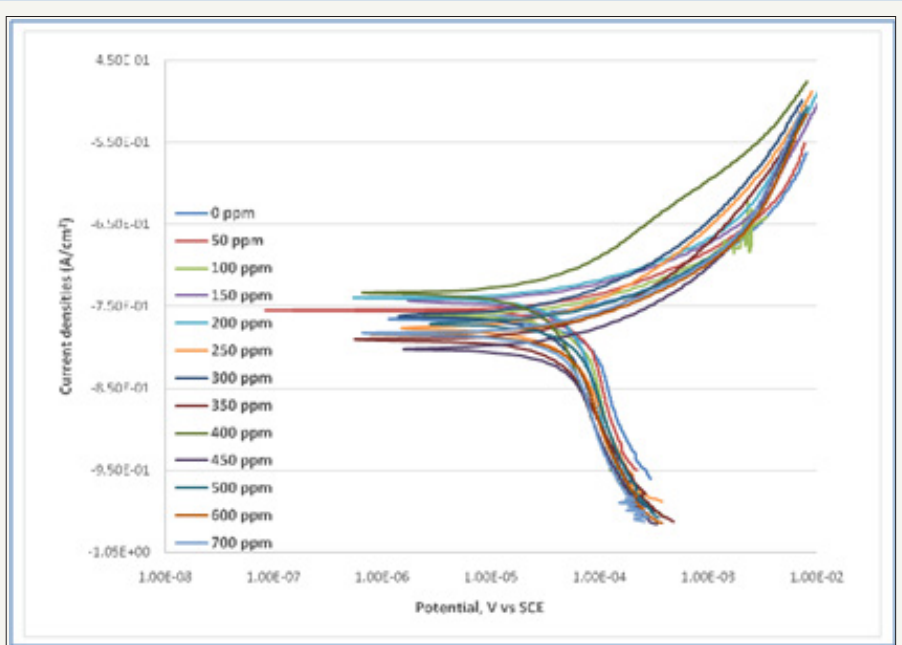

Figure 1: Electrochemical polarization curves for API 5L Steel in artificial brine solution with $\mathrm{CO}_{2}$ gas injection in the absence and presence of various concentrations of extract.

Figure 1 shows electrochemical polarization curves for API 5L steel in artificial brine solution with $\mathrm{CO}_{2}$ gas injection in the absence and presence of various concentrations of extract. The addition of dimocarpus longan peel extract to artificial brine solutions affects both the anodic and cathodic parts of the curve. In addition, the decrease of anodic current density in anodic site and cathodic currents density in cathodic site indicate the positive perfomance for green corrosion inhibitor of dimocarpus longan peel extract. On the other hand, it implied that the addition of extract to artificial brine solution reduces both the anodic dissolution of metal and also impedes the cathodic oxygen reduction reaction. On the basis of present work, the shift of Ecorr is less than $\pm 85 \mathrm{mV}$ vs SCE and dimocarpus longan peel extract acts as mixed type inhbitor as well as CIFE [15].

\section{Electrochemical impedance spectroscopy}

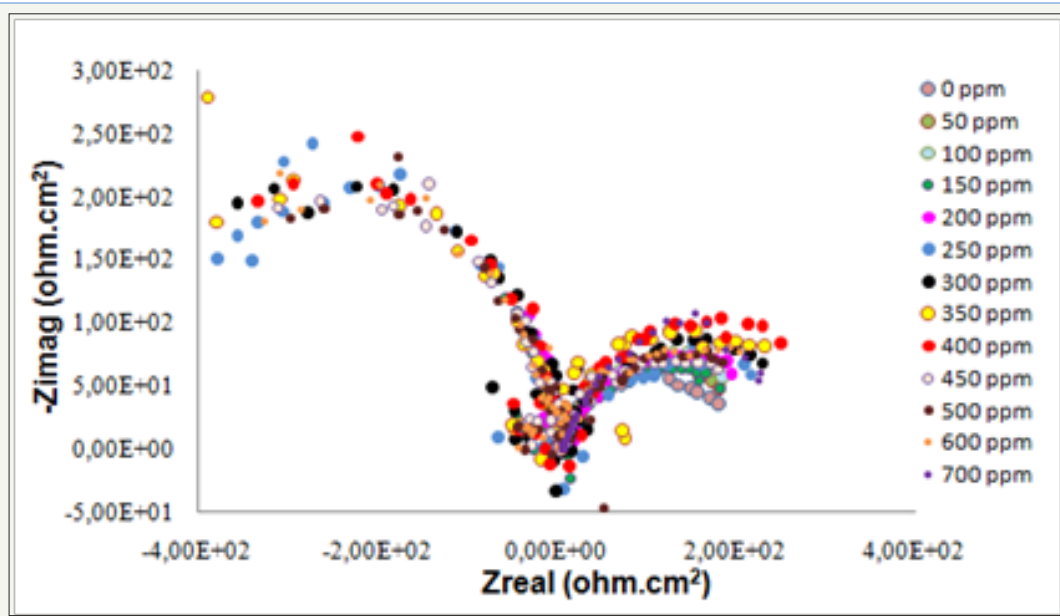

Figure 2: Nyquist plot for API 5L steel in artificial brine solution with $\mathrm{CO}_{2}$ gas injection in the absence and presence of various concentrations of extract.

Nyquist plots of API 5L steel in artificial brine solution with $\mathrm{CO}_{2}$ gas injection in the absence and presence of various concentrations of CIFE are given in Figure 2, where it can be observed that the diameter of the semicircle increases with increasing concentration of dimocarpus longan peel extract. Figure 2 shows that the impedance spectra are not perfect semicircles shape, which indicated deviation of the electrode of API 5L steel from ideal capacitive behaviour. This type of deviation (depressed capacitive loops) is often shown by the systems due to surface heterogeneity and irregularity, which may be the result of surface roughness, distribution of the active sites, or adsorption of the inhibitor molecules $[16,17]$.

Furthermore, on the basis of results in Table 3, the value of charge transfer resistance $\left(\mathrm{R}_{\mathrm{p}}\right)$ increased with increasing concentration of inhibitor. The increase in $R_{p}$ values is attributed to 
the formation of an insulating protective film at the metal/solution interface, which means the blocking process of the active sites by the film, formed bt the inhibitor at surface of metal [15]. In addition, Priyotomo et al. [18] had reported that the presence of dimocarpus longan peel extract enhances the values of $\mathrm{Rp}$ and reduces significantly double layer capacitance (CDl) values in acid solution but not $\mathrm{CDl}$ in artificial brine solution. $\mathrm{CDl}$ of present work is almost constant in increase of extract, where the decrease in Cdl results from a decrease in local dielectric constant and/or an increase in the thickness of the electric double layer [19]. This indicate that the increase in $R_{p}$ values, increase in inhibition efficiency up to $400 \mathrm{ppm}$ of extract concentration might be due to the gradual replacement of water molecules by the adsorption of the extract molecules on the metal surface, decreasing the extent of the dissolution reaction $[20,21]$.

Table 3: Impedance parameters for the corrosion of API 5L steel in artificial brine solution at the absence and presence of various concentrations of Dimocarpus longan peel extract.

\begin{tabular}{|c|c|c|c|}
\hline $\begin{array}{c}\text { Concentration } \\
(\mathbf{p p m})\end{array}$ & $\mathbf{R}_{\mathbf{u}}(\mathbf{o h m})$ & $\mathbf{R}_{\mathbf{p}}(\mathbf{o h m})$ & $\mathbf{C}_{\mathbf{f}}$ (farad) \\
\hline 0 & 6.177 & 119.3 & $8.49 \mathrm{E}-05$ \\
\hline 50 & 6.021 & 121.5 & $1.04 \mathrm{E}-04$ \\
\hline 100 & 6.081 & 122.7 & $1.03 \mathrm{E}-04$ \\
\hline 150 & 6.024 & 133.2 & $1.04 \mathrm{E}-04$ \\
\hline 200 & 5.507 & 140.1 & $1.30 \mathrm{E}-04$ \\
\hline 250 & 6.118 & 146.8 & $7.99 \mathrm{E}-05$ \\
\hline 300 & 2.037 & 159.5 & $1.07 \mathrm{E}-04$ \\
\hline 350 & 1.034 & 195.9 & $1.18 \mathrm{E}-04$ \\
\hline 400 & $1.29 \mathrm{E}-04$ & 202.3 & $1.11 \mathrm{E}-04$ \\
\hline 450 & 1.846 & 143.5 & $1.19 \mathrm{E}-04$ \\
\hline 500 & 2.18 & 134.9 & $8.81 \mathrm{E}-05$ \\
\hline 600 & 1.988 & 155.2 & $9.28 \mathrm{E}-05$ \\
\hline 700 & 8.203 & 179.1 & $8.98 \mathrm{E}-05$ \\
\hline
\end{tabular}

\section{Adsorption isotherm and standard adsorption free energy}

Adsorption exhibits an essential role in the inhibition of metallic corrosion by organic inhibitors. Many researchers have applied the Langmuir adsorption isotherm to study inhibitor characteristics $[22,23]$. In addition, the Langmuir adsorption isotherm assumes that the inhibitors adsorbed on the metal surface decrease the surface area available for cathodic and anodic reaction to take place [24]. The small surface of anodic and cathodic reaction on metal can reduces corrosion process. Furthermore, correlation between surface coverage $(\theta)$ defined by $\mathrm{E} \% / 100$ and the Langmuir adsorption isotherm, the isotherm is given by $[19,25]$ can represent the concentration of inhibitor (C):

$$
\frac{C}{\theta}=\frac{1}{K_{a d s}}+C(2)
$$

Where $\mathrm{K}_{\text {ads }}$ is the adsorption constant, $\mathrm{C}$ is the concentration of the inhibitor and surface coverage values $(\theta)$ are obtained from electrochemical measurements for various concentrations. The adsorption isotherm parameters and correlation coefficients found from the slopes and intercepts up to $400 \mathrm{ppm}$ of extract concentration, where the deviation of linear line occurs above $400 \mathrm{ppm}$ of it in Figure 2.

The slopes of Langmuir's plots are almost unity, indicating that the adsorption of Dimocarpus longan peel inhibitor onto API 5L steel obeys Langmuir isotherm. Furthermore, according to linear equation of $y=1.1346 x+0.3542$, Langmuir isotherm shows the best fit to Dimocarpus longan peel up to $400 \mathrm{ppm}$ of concentration. In addition, the higher value of $\mathrm{K}_{\text {ads }}$ indicates stronger adsorption of the inhibitor on steel surface and higher inhibiting effect [26], where the $\mathrm{K}_{\text {ads }}$ of Dimocarpus longan peel (DLP) is 2.824. The $\mathrm{K}_{\text {ads }}$ of DLP is higher than that of ginger and turmeric [26], which DLP has potency for inhibiting corrosion on steel surface.

\section{Conclusion}

The present study shows Indonesian dimocarpus longan peel extract acts as an effective inhibitor for API 5L steel corrosion in artificial brine water with injected $\mathrm{CO}_{2}$ gas. The inhibition efficiency increased with increase in inhibitor concentration up to $400 \mathrm{ppm}$ but decreased above it. The polarization plots indicated that the inhibitor inhibits both anodic metal dissolution and cathodic oxygen reduction reaction and act as mixed type inhibitors. Impedance measurements indicate that with increasing inhibitor concentration. The adsorption by the Langmuir isotherm is the best fitting between the coverage surface and concentration we conclude that the carbon steel surface obeys the Langmuir adsorption isotherm.

\section{Acknowledgment}

This work was completed thanks to all researchers and students at laboratory of corrosion in Research Center for Metallurgy \& Material, Indonesian Institute of Sciences. The authors also acknowledge the full support of Indonesia government grant for research, manuscript preparation and publication.

\section{References}

1. Eddy NO, Ebenso EE (2008) Adsorption and inhibitive properties of ethanol extracts of musa sapientum peels as a green corrosion inhibitor for mild steel in H2SO4. Afri J Pure Appl Chem 2(6): 46-54.

2. Khaled KF (2003) The inhibition of benzimidazole derivatives on corrosion of iron in 1M HCl. Electrochemical Acta 48(17): 2493-2503.

3. Raja PB, Sethuraman MG (2009) Solanum tuberosum as an inhibitor of mild steel corrosion in acid media. Iran J Chem Eng 28(1): 77-84.

4. Mohana KNS (2012) Centella asiatica extracts as green corrosion inhibitor for mild steel in $0.5 \mathrm{M}$ sulphuric acid medium. Adv Appl Sci Res 3(5): 3097-3106.

5. Mecke A, Lee I, Baker JR, Banaszak MMH, Orr BG (2004) Deformability of poly (amidoamine) dendrimers. Eur Phys J E 14(1): 7-16.

6. Luigi T, Luca D (2009) Propulsion physics EDP Sciences. Les Ulis.

7. De Lillo F, Cecconi F, Lacorata G, Vulpiani A (2008) Sedimentation speed of inertial particles in laminar and turbulent flows. Europhysics Letters 84(4): 1-8.

8. Ehteram A, Noor (2007) Temperature effects on the corrosion inhibition of mild steel in acidic solutions by aqueous extract of fenugreek leaves. Int J Electrochem Sci 2: 996-1017. 
9. Lebrini M, Robert F, Roos C (2011) Alkaloids extract from Palicourea guianensis plant as corrosion inhibitor for C38 steel in 1M hydrochloric acid medium. International Journal of Electrochemical Science 6(3): 847-859.

10. Vrsalovic, Kliskic M, Gudic S (2009) Aplication of phenolic acids in the corrosion protection of Al-0.8Mg alloy in chloride solution. Int J Electrochem Sci 4: 1568-1582.

11. Vimala JR, Rose LA, Raja A (2012) A study on the phytochemical analysis and corrosion inhibition on mild steel by Annona muricata leaves extract in 1N hydrochloric acid. Der Chemica Sinica 3(3): 582-588.

12. Worasuttayangkurn RL, Bennett RN, Satayavivad J (2005) Identification and quantification of polyphenolic compounds in Longan (Euphoria longana Lam.) fruit. J Agr Food Chem 53(5): 1387-1392.

13. Kassim MJ, Kang Wei T (2012) The proceedings of $2^{\text {nd }}$ annual international conference syiah kuala university 2012 \& $8^{\text {th }}$ IMT-GT Uninet Biosciences Conference. Banda Aceh, Indonesia, p. 183.

14. Rahim AA, Rocca E, Steinmetz J, Kassim MJ, Adnan R, et al. (2007) Mangrove tannins and their flavanoid monomers as alternative stee corrosion inhibitors in acidic medium. Corros Sci 49(2): 402-417.

15. Mathina A, Rajalakshmi R (2016) Corrosion inhibition of mild steel in acid medium using canna indica as green corrosion inhibitor. RAYASAN J Chem 9(1): 56-66.

16. Solomon M, Umoren SA, Udosoro II, Udoh AP (2010) Inhibitive and adsorption behaviour of carboxymethyl cellulose on mild steel corrosion in sulphuric acid solution. Corros Sci 52: 1317-1325.

17. Fawcett WR, Kovacova Z, Motheo AJ, Foss CA (1992) Application of the ac admittance technique to double-layer studies on polycrystalline gold electrodes. J Electroanal Chem 326(1-2): 91-103.
18. Priyotomo G, Nuraini L (2016) Proceeding of SENAMM IX 2016, Cilegon, Indonesia, pp. 167.

19. Bentiss F, Traisnel M, Lagrenee M (2000) The substituted 1,3,4-oxadiazoles: a new class of corrosion inhibitors of mild steel in acidic media. Corros Sci 42(1): 127-146.

20. Lagrenee M, Mernari B, Bouanis M, Traisnel M, Bentiss F (2002) Study of the mechanism and inhibiting efficiency of 3,5-bis (4 methylthiophenyl)$4 \mathrm{H}-1,2$, 4-triazole on mild steel corrosion in acidic media. Corros Sci 44(3): 573-588.

21. Muralidharan S, Phani KLN, Pitchumani S, Ravichhandran S, Iyer SVK (1995) Polyamino-benzoquinone polymers: a new class of corrosion inhibitors for mild steel. J Electrochem Soc 142: 1478-1483.

22. Hoar TP, Holliday RD (1953) The inhibition by quinolines and thioureas of the acid dissolution of mild steel. J Appl Chem 3(11): 502-513.

23. Meakins JR (1963) Alkyl quaternary ammonium compound as inhibitors of the acid corrosion of steel. Journal of Applied Chemistry 13(8): 339345 .

24. Kumpawat N, Chaturvedi A, Upadhyay RK (2012) Comparative study of corrosion inhibition efficiency of naturally occurring ecofriendly varieties of holy basil (Tulsi) for Tin in HNO3 solution. Open Journal of Metals 2(3): 68-73.

25. Langmuir I (2007) The constitution and fundamental properties of solids and liquids. II Liquids. J Amer Chem Soc 39: 1848-1917.

26. Ahamad I, Prasad R, Quraishi MA (2012) Adsorption and inhibitive properties of some new mannich bases of isatin derivatives on corrosion of mild steel in acidic media. Corros Sci 52: 1472-1481.
Creative Commons Attribution 4.0 International License

For possible submissions Click Here
Submit Article

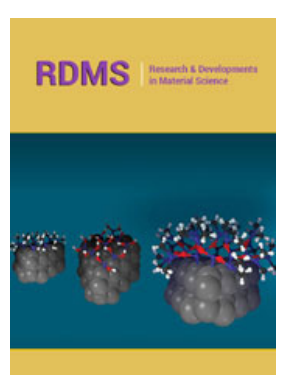

Research \& Development in Material Science

\section{Benefits of Publishing with us}

- High-level peer review and editorial services

- Freely accessible online immediately upon publication

- Authors retain the copyright to their work

- Licensing it under a Creative Commons license

- Visibility through different online platforms 